\title{
Property Rights, Land and Territory in the European Overseas Empires
}

Direitos de Propriedade, Terra e Território nos Impérios Ultramarinos Europeus

Edited by José Vicente Serrão

Bárbara Direito, Eugénia Rodrigues

and Susana Münch Miranda 
(C) 2014 CEHC-IUL and the authors.

All rights reserved.

Title: Property Rights, Land and Territory in the European Overseas Empires.

Edited by: José Vicente Serrão, Bárbara Direito, Eugénia Rodrigues, Susana Münch Miranda.

Editorial Assistant: Graça Almeida Borges.

Year of Publication: 2014.

Online Publication Date: April 2015.

Published by: CEHC, ISCTE-IUL. Avenida das Forças Armadas, 1649-026 Lisboa, Portugal. Tel.: +351 217903000. E-mail: cehc@iscte.pt.

Type: digital edition (e-book).

ISBN: 978-989-98499-4-5

DOI: $10.15847 /$ cehc.prlteoe. 945 X000

Cover image: “The home of a 'Labrador' in Brazil”, by Frans Post, c. 1650-1655 (Louvre Museum).

This book incorporates the activities of the FCT-funded Research Project (PTDC/HIS-HIS/113654/2009)

"Lands Over Seas: Property Rights in the Early Modern Portuguese Empire".

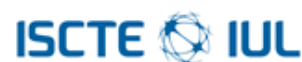

Instituto Universitário de Lisboa

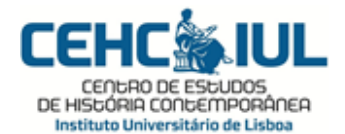

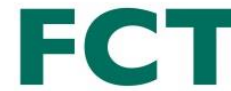

Fundação para a Ciência e a Tecnologia 


\section{Contents | Índice}

\section{Introduction}

Property, land and territory in the making of overseas empires

José Vicente Serrão

\section{Part I Organisation and perceptions of territory} Organização e representação do território

1. Ownership and indigenous territories in New France (1603-1760) Michel Morin

2. Brazilian landscape perception through literary sources (16th-18th centuries) Ana Duarte Rodrigues

3. Apropriação econômica da natureza em uma fronteira do império atlântico português: o Rio de Janeiro (século XVII) Maria Sarita Mota

4. A manutenção do território na América portuguesa frente à invasão espanhola da ilha de Santa Catarina em 1777

Jeferson Mendes

5. Urbanística e ordenamento do território na ocupação do Atlântico: as ilhas como laboratório Antonieta Reis Leite

6. Do mar à serra: a apropriação do solo na ilha da Madeira Nelson Veríssimo

7. Cartografia de uma propriedade na ilha de São Miguel: as Furnas de José do Canto (século XIX)

Pedro Maurício Borges

\section{Part II European institutions in colonial contexts} Instituições europeias em contextos coloniais

8. Bens, direitos e rendimentos no reino e na América portuguesa: o morgado e a capitania (século XVI) Maria Leonor García da Cruz

9. Capelas e terras de ónus de missa na ilha do Fogo, Cabo Verde (séculos XVIXVIII) Maria João Soares

10. Valorização e exploração do património vinculado em São Miguel (séculos XVIIXVIII) José Damião Rodrigues

11. História da propriedade eclesiástica nos Açores: o património do convento de São João de Ponta Delgada (século XVII) Graça Delfim

12. A exploração da terra sob o regime da colonia no arquipélago da Madeira João Palla Lizardo

3. A persistência dos sistemas tradicionais de propriedade fundiária em Damão e Baçaim (século XVI) Luís Frederico Dias Antunes

14. Property rights and social uses of land in Portuguese India: the Province of the North (1534-1739) Susana Münch Miranda 
Part III Colonial land policies Políticas de terras coloniais

15. The Portuguese land policies in Ceylon: on the possibilities and limits of a process of territorial occupation José Vicente Serrão

16. Influência política, ocupação territorial e administração (in)direta em Timor (1702-1914) Manuel Lobato

17. A expulsão dos jesuítas e a secularização da propriedade da terra no Pará do Setecentos José Alves de Souza Junior

18. Conquest, occupation, colonialism and exclusion: land disputes in Angola Mariana Pinho Candido

19. Labour exploitation and the question of land rights in colonial Malawi (Nyasaland) Davemonie Sawasawa

20. Regime de terras e cultivo de algodão em dois contextos coloniais: Uganda e Moçambique (1895-1930) Albert Farré

21. African access to land in early 20th century Portuguese colonial thought Bárbara Direito

\section{Part IV Property, society and conflict} Propriedade, sociedade e conflito

22. Traders, middlemen, smugglers: the Chinese and the formation of colonial Timor (18th-19th centuries) Paulo Jorge de Sousa Pinto

23. As repercussões do elitismo colonial português na exploração da terra em Moçambique (século XX) Martinho Pedro

24. Direito à terra e ao território em Moçambique no período colonial e após a independência José Gil Vicente

25. Land law and polygamy in the Bamiléké tribe in Cameroon Mathurin Clovis Tadonkeng

26. As dívidas do açúcar na capitania de Pernambuco (século XVIII)

Teresa Cristina de Novaes Marques

27. Territorialidade e sentidos da posse da terra na Zona da Mata de Pernambuco Ana Luísa Micaelo

28. The transformation of the property regime in 19th century Argentina Federico Benninghoff Prados 


\title{
The transformation of the property regime in 19th century Argentina
}

\author{
Federico Benninghoff Prados'
}

\begin{abstract}
Historians tend to characterize the system of land tenure in Spanish America as a patchwork of legal norms and customary practices, in which absolute private ownership constituted only one among many forms of land rights. In the decade following independence, Argentina's statesmen strove to monopolize land ownership in the hands of the central government, but their failure gave way in the 1830 s to a regime in which the assignment of property rights was closely linked to military service in frontier areas, expropriations and concessions in politically disputed zones, and the acquisition of huge tracts of public land by large landowners (mostly treasury creditors). From the 1860s onward, a political consensus emerged that made the massive sale of public land and the granting of absolute private ownership the backbone of the property regime. By the 1880s, a dynamic land market (in the modern sense) was perfectly recognizable. This study aims at analysing the transformation of the property regime in $19^{\text {th }}$ century Argentina, particularly in the province of Buenos Aires, from two interrelated points of view: on the one hand, a perspective that stresses the developments in the Atlantic market and in the sphere of economic production; on the other, a perspective that explores the emergence of the institutional framework that allowed the State to exert a more effective territorial control, both in the administrative and in the military sense, and thus lay the foundations for a capitalist property regime.
\end{abstract}

Resumo: Os historiadores tendem a caracterizar o sistema de posse da terra na América espanhola como uma manta de retalhos de normas jurídicas e práticas consuetudinárias, em que a propriedade privada absoluta constituía apenas uma entre várias formas de direitos sobre a terra. Após a independência, os estadistas argentinos procuraram monopolizar a propriedade da terra, colocando-a nas mãos do governo central, mas o seu fracasso abriu caminho na década de 1830 a um regime em que a atribuição de direitos de propriedade estava intimamente ligada ao serviço militar em zonas de fronteira, a expropriações, a concessões em zonas politicamente disputadas e à aquisição de enormes parcelas de terras públicas por grandes proprietários. A partir 1860, um consenso político tornou a venda maciça de terras públicas e a propriedade privada absoluta os fundamentos do regime de propriedade. Na década de 1880, um dinâmico mercado de terras era perfeitamente reconhecível. Este estudo pretende analisar as transformações ocorridas no sistema de propriedade na Argentina no século XIX, em especial na província de Buenos Aires, a partir de dois pontos de vista relacionados entre si: por um lado, uma perspectiva que sublinha os desenvolvimentos ocorridos no mercado atlântico e na esfera da produção económica; por outro, uma perspectiva que explora a emergência de um quadro institucional que permitiu ao Estado exercer um controlo territorial (administrativo e militar) mais efectivo e assim lançar as bases de um regime de propriedade capitalista.

\footnotetext{
${ }^{1}$ University of Konstanz, Department of History and Sociology, Germany, febenning@ yahoo.com.

José Vicente Serrão, Bárbara Direito, Eugénia Rodrigues, Susana Münch Miranda (eds.). Property Rights, Land and Territory in the European Overseas Empires. Lisbon: CEHC-IUL, 2014. ISBN: 978-989-98499-4-5.
}

(C) 2014 CEHC-IUL and Federico Benninghoff Prados. Chapter DOI:10.15847/cehc.prlteoe.945X028. 
round 1736 the Jesuit missionary and historian Pedro Lozano described the
territory south of the Río de la Plata as follows:

"This extended district is an endless plain, running from Cape Blanco in the North Sea to the foothills of the Cordilleras of Chile, forming a famous desert called the pampas, an hispanicised word typical of the general Quechua language in the Peruvian empire that means open country [...] the paths connecting cities along its fringes had to be marked out with needle [compass] and it is still necessary to use it: you can't take one single step inland without it, just as if you were navigating in the seas, because you will find nothing but endless sky and land [...]" (Lozano 1874: $150)$.

The metaphor of oceanic infinity to convey the vastness of the pampas was commonplace in colonial Río de la Plata, and it became indeed a recurring image in the process of state-building in $19^{\text {th }}$ century Argentina: many settlers, soldiers, missionaries, and officials who travelled the plains described themselves as mainland sailors. One of the fundamental questions, paraphrasing the metaphorical figure, was to find the right property regime to build a state on this ocean. This brief historical overview focuses on the lands on the southern border of the provinces of the Río de la Plata, particularly in the province of Buenos Aires, and examines on the one hand some features of the agrarian production and what may be called the "military-cadastral complex" on the other.

\section{Enfiteusis and political centralization}

After the disruptions caused by the revolutionary wars in the $1810 \mathrm{~s}$, the answer to the question of the property regime in the 1820 s became statist in nature: the Argentine state claimed ownership over wastelands, according to the tradition established by the Spanish crown, but public lands could only be leased in long-term contracts (enfiteusis) without entitlement to private ownership. The prohibition of public land sales was first established in Buenos Aires in 1822 and then extended to the national territory in 1826. Supporters of these twenty-year lease arrangements sought, in the first place, to use public land as collateral to back up external lending, which in turn would provide the fiscal basis of public credit. On the other hand, lease contracts would allow, at least in theory, the productive incorporation of new land in the context of an under-capitalized economy (Ferns 1960: 100-105; Gautreau and Garavaglia 2011: 63-67; Halperin Donghi 2005: 132-191). It has been pointed out that the most dynamic form of production in this period, extensive cattle ranching specialized in hides, tallow and jerked beef, and oriented largely toward the slave economies of Brazil and Cuba, didn't necessarily match the political project of a centralized state based on the administrative control over public land. The producers' main concern was the management and control of cattle herds and only secondarily were they interested in ownership of land (Gelman and Santilli 2006: 75-112; Míguez 2008: 93-125). In this context of open frontiers, land could hardly be subjected to any form of "artificial scarcity".

The literature on $19^{\text {th }}$ century Argentina has paid less attention to the bureaucratic instruments available to the government in its implementation of the long-term leasing strategy. The newly created Topographical Commission (1824) was supposed to play a key role in the organization and supervision of land rights, as hoped by Juan Gregorio de Las Heras, governor of Buenos Aires, in 1825: "In order to secure rural properties it has been necessary to find a means to fix the boundaries of each possession and to remove all the uncertainties that prevailed so far, without the guarantees that only science is able to provide in this country as flat as the sea" (De las Heras 1976: 39). Renamed two years later as the General Topographic and Statistical Department, it 
lacked the administrative and financial resources to undertake the surveys directly. Former proprietors, interested in validating or legalizing their titles, as well as new leaseholders under the enfiteusis system had - theoretically at least - to contract private surveyors accredited by the department, which in turn was responsible for supervising the private surveys and standardizing the collected information in the cadastre (Gautreau and Garavaglia 2011).

Civil wars, armed conflicts with indigenous communities on the frontiers, and the international war with Brazil drained the resources of the central executive and eroded the fiscal and administrative support for the department's supervision and mapping activities. Unable to exercise the monopoly on violence or to transform its army into a powerbroker, the central state failed to transform public property over land - and therefore long-term lease arrangements - into a pivotal axis of state-building. Without the means to survey the ocean of the pampas or to back up its territorial claims militarily, the public monopoly on land was simply unfeasible.

\section{Juan Manuel de Rosas: restricted property rights}

The failure of centralization in Argentina engendered political fragmentation and eroded the existing institutional framework. During his tenure as governor of Buenos Aires between 1829-1832 and 1835-1852, Juan Manuel de Rosas introduced major changes in the property regime of the richest province in La Plata basin. Rosas' land policy was extremely eclectic, and the provincial government drew on expedients inherited both from the colonial period and the republican experience: conditional and unconditional grants, massive sell-offs and long-term leases were all part of the administrative repertoire. In 1829, shortly before his first election as governor and acting as commanding general of the militias in the countryside, Rosas challenged the prevailing property regime by issuing land grants through Justices of the Peace without the intervention of the Topographic Department (Martínez Sierra 1975: 128). In establishing "personal merit" as an allocation criterion, Rosas set a precedent that set the tone during his whole tenure: a hybrid property system intended to back up an intense political and military mobilization. For example, the massive sale of public lands between 1836 and 1839 provided the province with substantial fiscal resources at a time when military campaigns in Uruguay and the French blockade of Buenos Aires strained public finances, in the same way that expropriations and grants in the 1840s rewarded or punished military and political loyalties in the first phase (1839-1842) of the so called Guerra Grande (1839-1851) (Infesta and Valencia 1987: 184-196). A property regime subjected to the needs of political and military mobilization, with substantial discretionary powers in the hands of the executive to sell, grant or expropriate land, allowed the government to overcome international military engagements, internal uprisings and civil wars, but it rallied opponents against its alleged arbitrariness and exacerbated the inherent insecurity of the property rights bestowed. Most contemporary critics and classic authors emphasized unconditional grants as irrefutable proof of the arbitrariness of the property regime during Rosas' tenure (cf. Cárcano 1972: 69-75). The comprehensive study of Infesta and Valencia (1987) has shed new light on the subject: if the issue is examined not from the point of view of the land grants awarded, but from the point of view of those grants that actually led to property titles, it may be concluded that unconditional grants were less important than traditionally assumed. But it is still true that, in comparative terms, Rosas' 
government concentrated extensive discretionary powers in the executive as far as land policy is concerned.

The "restricted" nature of property during Rosas' tenure did not derive exclusively from the discretional powers to allocate (or revoke) rights; it was also due to the persistence of customary rights and subsistence practices in the countryside. Rosas himself had to deal with this reality: repeated instructions to his estate managers to prevent rural dwellers from hunting wild animals and gathering firewood (or eventually to tolerate this activities) on his lands reflect the difficulties he faced in order to secure - through legal property - exclusive rights to the land and its resources. No less revealing are the problems caused by the eviction of established tenants in the lands that he acquired, or the need to tolerate and even favour the establishment of "independent settlers". Despite the fact that their economic activities often interfered with the estates' own production, there were tangible benefits: in addition to providing temporary labour, settlements on the fringes of his estates helped to delimit them from neighbouring properties and to prevent cattle rustling. Whether favoured, tolerated or condemned, the fact is that the presence of precarious landholders, peasants, squatters, "independent settlers" and even large cattle owners in the lands of the governor constitutes a reliable indicator of the "restricted" nature of land ownership in the first half of the $19^{\text {th }}$ century (Gelman 1998).

Unsurprisingly, the activity of the Topographic Department declined sharply, and Rosas himself gave final approval to some of the surveys remitted by proprietors and lessees: the provincial governor had little interest in an autonomous entity responsible for the regulation of land rights (Garavaglia 2011: 54; Gautreau and Garavaglia 2011: 72). The restricted nature of property hindered the governor from exploiting his lands in an exclusive manner, but it allowed him to articulate a broad political-military network, which linked Buenos Aires' institutional framework with loyal landowners and the rural population. If the centralist policies of the 1820 s were based on the public monopoly of the ocean of the pampas, Rosas tried in the 1830s and 1840s a sort of mosaic variant that involved dividing the waters for the benefit of his political-military network while at the same time denying access to his opponents.

\section{The consolidation of full-fledged private property}

The restricted and comparatively insecure nature of property rights manifested itself in the multiple claims filed after the defeat of the governor of Buenos Aires in 1852. The demands of the victims of expropriations by Rosas were offset against the assertions of those advocating for the recognition of legitimate rights granted during his tenure. Usufructuary, leasing and property rights over the same lands could be claimed by their respective holders, who resorted to different and partially contradictory laws, relied on long occupation periods and objected inaccurate land records to legitimize their claims (Cárcano 1972: 113-124). In institutional circles land policy became a major subject of debate and a large majority supported exclusive rights as the cornerstone of the entire system: usufructs, leases or informal tenures should be regularized as private property, dubious titles legalized and public land completely alienated through massive privatizations.

The importance attributed to the debate was in response to the pressure to dismantle the alleged arbitrariness and factious nature of the property regime crafted by Rosas, but it also reflected the changing conditions of production. Land had become comparatively scarce and the inability to occupy and settle the territories controlled by independent indigenous communities set a limit to the expansion of the land market. Moreover, 
Argentina's growing integration into the industrializing economies in Europe was also transforming the rural landscape. The rapid expansion of sheep farming provides a good example of such change. Unlike traditional extensive cattle ranching, wool production for the European - mainly French, Belgian, and German - textile industry required land improvements, which promised high returns and increased the value of land, transforming it into a highly prized commodity and a key factor of production (Míguez 2008: 118-121; Sabato 1989). Many state officials and entrepreneurs supported since the middle of the $19^{\text {th }}$ century the formula proposed by the future president Nicolás Avellaneda in 1865:

\begin{abstract}
"Property and irrevocable property. Conditional grants, long term and short term leases only provide labour and capital with an uncertain and insecure foundation [...] Let us put the lands already occupied or to be occupied out of state dominion in order to keep them from the dissolvent action of the laws governing public property. Let us grant private property rights, firm and unchangeable, so they can serve as a permanent foundation to labour, as man's place on earth and as independent home for the family" (Avellaneda 1944: 104-105).
\end{abstract}

Despite the broad consensus around the mantra of private property, there were no immediate privatizations after Rosas fall. Buenos Aires banned the sale of public land and organized a system of eight-year leases. This land policy reflected both circumstantial concerns and basic considerations. Many feared that Justo José de Urquiza, governor of Entre Ríos and commander of the Ejército Grande that defeated Rosas, would rely on uncontrolled land grants to reward his retinue and shore up his political and military power. Beyond this immediate concern, it was necessary to devise a transitional strategy that, without ignoring the claims of expropriated owners, former lessees and non-titled landholders, would lay the foundations of a full-fledged private property regime. Preferential purchase rights were granted to the new holders, and successive laws issued between 1857 and 1878 led to massive sell-offs of public land under lease. Simultaneously, laws issued in 1857 and 1859 put up 540,000 hectares directly for auction (Valencia 2005: 65-155).

In the province of Buenos Aires at least 9 million hectares went into private hands between 1867 and 1880. By then, a modern and dynamic private land market - both physically and legally - was firmly established (Cortés Conde 1979: 150-152). A market in which the allocation of land, defined as property in absolute terms, was basically determined by supply and demand, and only secondarily by direct executive intervention or the existence of alternative tenure regimes. This process was fuelled by the tighter coupling between organized violence and bureaucratic management of land allocation, expressed for example in the creation of the Military Topographic Office after the so called "Conquest of the Desert" by Julio A. Roca in 1879. The consolidation of a "military-cadastral complex" enabled the government to exert a more effective control over territory and lay the physical and institutional foundations of the new property regime. Roca's military campaign is the best example of such synergies: law 947 of October 5, 1878, provided for an issue of bonds worth 1,600,000 pesos (400 pesos each), redeemable in land. Each subscriber could buy the bonds in quarterly instalments of 100 pesos and was entitled to a maximum of 3 tracts in the territories to be occupied. Each league of land was valued at 400 pesos, and the property titles had to be issued within a period not longer than 5 years. Simultaneously with the expansion of the agrarian frontier and its military occupation, land was surveyed, divided into tracts of 10.000 hectares, registered in the cadastre, and auctioned among subscribers. In the case of two or more subscribers interested in the same tracts, the land had to be allocated by lot (Cárcano 1972: 168). 
By pushing the southern border to the Rio Negro in 1879 and consecrating absolute, exclusive private property, the Argentine state laid the foundations of a land market in the modern sense; a market that became one of the pillars of the unprecedented economic growth of the late nineteenth century. By then, Argentina's economy based in export agriculture had advanced towards diversification and the country became a major supplier of grain to the world market as well as the destination of large inflows of European labour and capital. While extensive cattle ranching accompanied the military vanguards in the occupation of the newly conquered territory, and sheep farming established itself in the rear, the oldest areas of settlement specialized in wheat production. Through short-term leasing and sharecropping arrangements, the new land regime allowed landowners access to domestic and international flows of labour. Through mortgage bonds, they took stakes in the booming capital market (Cortés Conde 1997: 15-78; Míguez 2008: 145-260). At the end of the century, the Argentine government had privatized its pampean ocean while simultaneously consolidating military and cadastral control; as a consequence of this double track process, land ownership offered unprecedented opportunities for investment, access to labour and to financial speculation.

\section{Conclusion}

The global historiography of recent years has brought a renewed emphasis on the massive allocation of private property rights over land as a crucial factor in the broad transformations experienced in the long $19^{\text {th }}$ century. Particularly in frontier and settlement areas, these rights were linked to the productive incorporation of millions of hectares to the capitalist world economy, to the destruction of native peoples around the world, and to the enduring ecological changes derived from an intensified and expanding agricultural production (Bayly 2004: 432-450; Osterhammel 2010: 465-564). In the Argentine historiography, the massive alienation of public lands and their transference to private hands has been acknowledged as one of the leitmotifs of the $19^{\text {th }}$ century (Cortés Conde 1997: 53-54; Míguez 2008: 105-106; Sabato 1989: 51-78). Examined from a bird's-eye view, this continuity in the Argentinian land policy matches the observations made in other world regions. However, a closer analysis of the development of the property regime in Argentina reveals the inconvenience of overstating continuities in the privatization process. This process was not univocal; it depended on a protean and contradictory constellation of factors. This brief overview has stressed, on the one hand, some of the most important changes in the agricultural production throughout the $19^{\text {th }}$ century. On the other hand, it has pointed out the importance of the interaction between military and cadastral structures embedded in the overarching state-building process.

The military weakness of the central executive in the 1820s and the nature of extensive ranching in an open frontier conspired against a political order based on public property and massive alienation of public land through long-term leases. In the 1830s and 1840s the Buenos Aires government reinforced the "restricted" nature of property by using land rights as a means of fuelling an intense political and military mobilization. The eclectic and discretionary use of sell-offs, grants and expropriations provided the resources that shored up Rosas' regime, but those expedients were at odds with the increased economic importance of land as a commodity and means of production. After the interregnum of eight-year lease arrangements in Buenos Aires, the 1870s witnessed the consolidation of the national state based on privatizations and the military 
occupation of the agrarian frontier: a tighter coupling of cadastral and military functions allowed the Argentinean state to centralize power and take advantage of the resources provided by an agrarian economy experiencing diversification and massive inflows of capital and labour. By the end of the long $19^{\text {th }}$ century, Argentina had a fully developed land market in a modern sense, based on unrestricted private property. This market was a sine qua non for the concomitant processes of rapid urbanization, economic diversification and social differentiation that shaped Argentine history in the twentieth century ${ }^{2}$.

\section{References}

Avellaneda, Nicolás. 1944 [1 $1^{\text {st }}$ ed. 1865]. Estudios sobre las leyes de tierras públicas. Buenos Aires: W.M. Jackson Editores.

Bayly, C. A. 2004. The Birth of the Modern World, 1780-1914: Global Connections and Comparisons. Malden, MA / Oxford: Blackwell.

Cárcano, Miguel Ángel. 1972 [1 $1^{\text {st }}$ ed. 1917]. Evolución histórica del régimen de la tierra pública 18101916. Buenos Aires: Eudeba.

Ferns, H. S. 1960. Britain and Argentina in the Nineteenth Century. Oxford: Clarendon Press.

Cortés Conde, Roberto. 1979. El progreso argentino 1880-1914. Buenos Aires: Sudamericana.

Cortés Conde, Roberto. 1997. La economía argentina en el largo plazo. Ensayos de historia económica de los siglos XIX y XX. Buenos Aires: Sudamericana / Universidad de San Andrés.

De las Heras, Juan Gregorio. 1976. "Mensaje del gobernador Juan Gregorio de las Heras. 18 de mayo de 1825". In Mensajes de los gobernadores de la Provincia de Buenos Aires 1822-1849, Vol. I., Provincia de Buenos Aires, La Plata: Archivo Histórico de la Provincia de Buenos Aires "Ricardo Levene", 38-41.

Garavaglia, Juan Carlos. 2011. “CCómo se mide la tierra? Las mensuras en el Río de la Plata, siglos XVIII-XIX”. In Mensurar la tierra, controlar el territorio. América Latina, siglos XVIII-XIX, ed. Juan Carlos Garavaglia and Pierre Gautreau, Rosario: Prohistoria, 27-61.

Gautreau, Pierre; and Garavaglia, Juan Carlos. 2011. "Inventando un nuevo saber estatal sobre el territorio: la definición de prácticas, comportamientos y agentes en las instituciones topográficas de Buenos Aires, 1824-1864”. In Mensurar la tierra, controlar el territorio. América Latina, siglos XVIII-XIX, ed. Juan Carlos Garavaglia and Pierre Gautreau, Rosario: Prohistoria, 63-96.

Gelman, Jorge. 1998. "Un gigante con pies de barro. Rosas y los pobladores de la campaña”. In Caudillos rioplatenses. Nuevas miradas a un viejo problema, ed. Noemí Goldman and Ricardo Salvatore, Buenos Aires: Eudeba, 223-240.

Gelman, Jorge; and Santilli, Daniel. 2006. Historia del capitalismo agrario pampeano. Vol. 3, De Rivadavia a Rosas. Desigualdad y crecimiento económico. Buenos Aires: Siglo XXI / Universidad de Belgrano.

Halperin Donghi, Tulio. 2005 [1 ${ }^{\text {st }}$ ed. 1982]. Guerra y finanzas en los orígenes del Estado argentino (1791-1850). Buenos Aires: Prometeo Libros.

Infesta, María Elena; and Valencia, Marta. 1987. "Tierras, premios y donaciones. Buenos Aires: 18301860". Anuario IEHS, n. 2: 177-213.

Lozano, Pedro. 1874. Historia de la conquista del Paraguay, Río De La Plata y Tucumán. Vol. I. Buenos Aires: Imprenta Popular.

\footnotetext{
${ }^{2}$ The author is very grateful to Sol Lanteri, Helena Pérez Niño and Edward Cavanagh for many helpful comments and suggestions. He is also indebted to the participants at the international conference "Property Rights, Land and Territory in the European Overseas Empires" (Lisbon, ISCTE-IUL, 26-27 June 2014) for the fruitful discussions.
} 
Martínez Sierra, Ramiro. 1975. El mapa de las Pampas. Vol. II. Buenos Aires: Ministerio del Interior.

Míguez, Eduardo José. 2008. Historia económica de la Argentina. De la conquista a la crisis de 1930. Buenos Aires: Sudamericana.

Osterhammel, Jürgen. 2010. Die Verwandlung der Welt. Eine Geschichte des 19. Jahrhunderts. Munich: Beck.

Sabato, Hilda. 1989. Capitalismo y ganadería en Buenos Aires: la fiebre del lanar 1850-1890. Buenos Aires: Sudamericana.

Valencia, Marta. 2005. Tierras públicas, tierras privadas. Buenos Aires, 1852-1876. La Plata: Universidad Nacional de La Plata. 